Dissolution of Highly Enriched Uranium from the Idaho National Engineering and Environmental Laboratory

Tracy S. Rudisill and David G. Karraker

October 2003 
This document was prepared in conjunction with work accomplished under Contract No. DE-AC09-96SR18500 with the U. S. Department of Energy.

\section{DISCLAIMER}

This report was prepared as an account of work sponsored by an agency of the United States Government. Neither the United States Government nor any agency thereof, nor any of their employees, makes any warranty, express or implied, or assumes any legal liability or responsibility for the accuracy, completeness, or usefulness of any information, apparatus, product or process disclosed, or represents that its use would not infringe privately owned rights. Reference herein to any specific commercial product, process or service by trade name, trademark, manufacturer, or otherwise does not necessarily constitute or imply its endorsement, recommendation, or favoring by the United States Government or any agency thereof. The views and opinions of authors expressed herein do not necessarily state or reflect those of the United States Government or any agency thereof.

This report has been reproduced directly from the best available copy.

Available for sale to the public, in paper, from: U.S. Department of Commerce, National Technical Information Service, 5285 Port Royal Road, Springfield, VA 22161, phone: (800) 553-6847, fax: (703) 605-6900

email: orders@ntis.fedworld.gov

online ordering: http://www.ntis.gov/help/index.asp

Available electronically at http://www.osti.gov/bridge

Available for a processing fee to U.S. Department of Energy and its contractors, in paper, from: U.S. Department of Energy, Office of Scientific and Technical Information, P.O. Box 62, Oak Ridge, TN 37831-0062,

phone: (865)576-8401,

fax: (865)576-5728

email: $\underline{\text { reports@ adonis.osti.gov }}$ 


\section{This page was intentionally left blank.}




\section{Table of Contents}

Section

Summary

Introduction

Experimental

X-ray Diffraction Analysis

Thermogravimetric Analysis

Offgas Characterization

Timed Dissolution Experiments

Results and Discussion

X-ray Diffraction Analysis

Thermogravimetric Analysis

Offgas Characterization

Timed Dissolution Experiments
Page

1

3

5

5

5

5

6

9

9

9

10

10

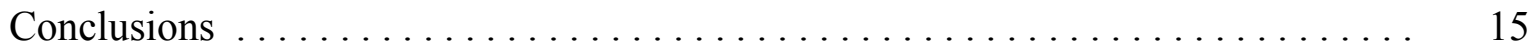

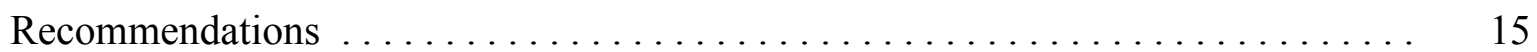

References $\ldots \ldots \ldots \ldots \ldots \ldots \ldots \ldots \ldots \ldots \ldots \ldots \ldots \ldots \ldots \ldots \ldots \ldots \ldots$ 


\section{List of Tables}

\section{Page}

Table $1 \quad$ Summary of Conditions for Offgas Characterization Experiments . . 6

Table 2 Summary of Conditions for Timed Dissolution Experiments . . . . 7

Table $3 \quad$ Measured U Concentrations Following HEU Dissolutions $\ldots \ldots \ldots$

Table $4 \quad$ U Recovery During HEU Dissolution Experiments $\ldots \ldots \ldots \ldots$

Table 5 Material Balances for HEU Dissolution Experiments $\ldots \ldots \ldots \ldots 12$

Table $6 \quad$ Estimated Composition of HEU from the INEEL $\ldots \ldots \ldots \ldots \ldots$

Table 7 Consumption of $\mathrm{HNO}_{3}$ during HEU Dissolution Experiments $\ldots \ldots \quad 14$

\section{List of Figures}

Figure $1 \quad$ Offgas Sampling and Measuring Equipment $\ldots \ldots \ldots \ldots \ldots \ldots \ldots$

Figure 2 X-ray Diffraction Spectrum from Sample $746 \ldots \ldots \ldots \ldots \ldots$

Figure $3 \quad$ X-ray Diffraction Spectrum from Sample $747 \ldots \ldots \ldots \ldots \ldots$

Figure $4 \quad$ TGA Curve for Sample $746 \ldots \ldots \ldots \ldots \ldots \ldots \ldots \ldots \ldots \ldots \ldots \ldots$

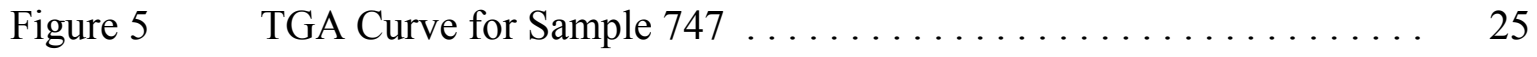

Figure $6 \quad$ Dissolution of HEU from the INEEL $\ldots \ldots \ldots \ldots \ldots \ldots \ldots \ldots$

Figure $7 \quad$ X-ray Diffraction Spectrum of Undissolved Solids . . . . . . . . . 29

\section{List of Appendices}

Appendix A Uranium Analyses from Timed Dissolution Experiments . . . . . . 31

Appendix B Correction of U Concentrations for Changes in Volume . . . . . . 33

Appendix C Elemental Analyses for HEU Dissolution Experiments $\ldots \ldots \ldots$ 


\title{
Dissolution of Highly Enriched Uranium from the Idaho National Engineering and Environmental Laboratory
}

\author{
Tracy S. Rudisill and David G. Karraker \\ Westinghouse Savannah River Company \\ Aiken, SC 29808
}

\section{Summary}

Since the capability to purify uranium (U) was terminated at the Idaho National Engineering and Environmental Laboratory (INEEL) in the early 1990's, excess highly enriched uranium (HEU) from the cleanout of uranium trioxide $\left(\mathrm{UO}_{3}\right)$ production equipment will be shipped to the Savannah River Site (SRS) for disposition. The excess material will be dissolved in Phase I of HB-Line, purified by solvent extraction, and blended with normal $U$ to an enrichment which can be used to fabricate fuel for Tennessee Valley Authority (TVA) reactors. The proposed HB-Line processing strategy is to dissolve up to $3 \mathrm{~kg}$ of material per $18 \mathrm{~L}$ dissolver batch. To demonstrate the proposed processing strategy, two samples of the HEU were shipped to the Savannah River Technology Center (SRTC). The material was used in a series of small-scale experiments in which prototypical amounts were dissolved to characterize the offgas and measure the dissolution time under varying process conditions.

Initially, an examination of the HEU by x-ray diffraction showed that the material was a mixture of $\mathrm{UO}_{3}$ and two monohydrated forms of $\mathrm{UO}_{3}$. Subsequent thermogravimetric analyses showed that the samples contained 8-9 wt\% volatile components which were predominately water. The dissolution of several grams of material from each sample in a closed system with the capability to measure and sample the offgas showed that essentially no gas was generated as the material dissolved. This observation was consistent with the presence of $\mathrm{UO}_{3}$ which generates no offgas upon dissolution in nitric acid $\left(\mathrm{HNO}_{3}\right)$. The generation of hydrogen $\left(\mathrm{H}_{2}\right)$ during the dissolution of the HEU is not a concern.

Complete dissolution of the $\mathrm{U}$ was obtained in 15-30 min for experiments performed at $23-60^{\circ} \mathrm{C}$. The HEU was dissolved in $3.5 \mathrm{M} \mathrm{HNO}_{3}$ using the solids to liquid ratio proposed for use in HB-Line. The experiment performed at $23^{\circ} \mathrm{C}$ demonstrated that rapid heat generation during the dissolution is not a concern. The temperature peaked $5 \mathrm{~min}$ into the dissolution at $28^{\circ} \mathrm{C}$ and quickly cooled back down to $23^{\circ} \mathrm{C}$. During filtration of the dissolving solutions, a small amount of black solids was collected; the material was identified as graphite by subsequent $\mathrm{X}$-ray diffraction analysis. A temperature of at least $60-70^{\circ} \mathrm{C}$ for the dissolution is recommended to minimize the amount of undissolved impurities.

Two additional dissolution experiments were performed at $80^{\circ} \mathrm{C}$ to characterize the $\mathrm{U}$ and impurity content of the HEU. Uranium and elemental analyses of the two dissolving solutions and the solutions generated by the offgas characterization experiments were used to estimate the composition of the HEU by assuming the impurities generally occurred in the material as oxides. 
The estimated composition of the samples shipped from INEEL was nominally $80 \mathrm{wt} \% \mathrm{UO}_{3}$, $10 \mathrm{wt} \%$ volatiles (primarily water), and $10 \mathrm{wt} \%$ oxide impurities. The principal impurity was aluminum oxide $\left(\mathrm{Al}_{2} \mathrm{O}_{3}\right)$. Accounting for the $\mathrm{UO}_{3}$, volatile components, and analyzed impurities (as oxides) resulted in material balance closures of 81-98\%. Analysis of the initial and final $\mathrm{HNO}_{3}$ concentrations of the dissolving solutions showed that $0.005-0.010$ mole of $\mathrm{HNO}_{3}$ was consumed per gram of HEU. To achieve a final $\mathrm{HNO}_{3}$ concentration of nominally $2 \mathrm{M}$, desired for subsequent solvent extraction operations, a starting $\mathrm{HNO}_{3}$ concentration of $3.0-3.5 \mathrm{M}$ is recommended. 


\section{Introduction}

To support the disposition of HEU from the INEEL, excess material will be shipped to the SRS for blending the ${ }^{235} \mathrm{U}$ content down to an enrichment which can be used to fabricate fuel for TVA reactors. The HEU was accumulated during cleanout of equipment used to produce a $\mathrm{UO}_{3}$

product. The HEU has been stored at the INEEL since the termination of reprocessing activities at the site. The HEU is scheduled for dissolution in Phase I of the HB-Line Facility. The U will then be purified by solvent extraction and blended with normal $U$ as part of the TVA Blenddown Program.

The proposed HB-Line processing strategy is to dissolve up to $3 \mathrm{~kg}$ of material per dissolver batch. The working volume of the Phase I dissolvers is nominally $18 \mathrm{~L}$ which will result in a final $\mathrm{U}$ concentration in the $100-120 \mathrm{~g} / \mathrm{L}$ range. A dissolution temperature of $60-70^{\circ} \mathrm{C}$ is desired; although, the Phase I dissolvers are capable of operating at or near the boiling point of the solution. A final $\mathrm{HNO}_{3}$ concentration of approximately $2 \mathrm{M}$ is desired to facilitate subsequent purification by solvent extraction. To develop and demonstrate a dissolution flowsheet with the features described above, two samples of the HEU were shipped to the SRTC. The material was used in a series of small-scale experiments to measure the time required to dissolve the HEU using conditions proposed for HB-Line. Experiments were also performed to measure and characterize the offgas and identify exothermic behavior during dissolution. Elemental analyses of dissolving solutions, x-ray diffraction analysis of the HEU and undissolved solids, and thermogravimetric analysis of the HEU were used to characterize the INEEL material. A description of the experiments performed and a discussion of the results are provided in the following sections. 


\section{This page was intentionally left blank.}




\section{Experimental}

\section{$\underline{\text { X-ray Diffraction Analysis }}$}

Since the HEU was removed from equipment utilized in the production of $\mathrm{UO}_{3}$, complete conversion to the intended product may not have occurred for all of the material. To determine the predominate forms of $U$ in the samples from the INEEL, approximately $100 \mathrm{mg}$ of each sample were analyzed by x-ray diffraction.

\section{Thermogravimetric Analysis}

Removal of the HEU from the INEEL production process also created the potential for the material to contain volatile components such as nitrogen and carbon-containing compounds and water. To detect and quantify the amount of these materials, $100 \mathrm{mg}$ of each INEEL sample were analyzed using a thermogravimetric analyzer (TGA) coupled to a mass spectrometer (MS). The mass loss of each sample was measured using a Netzsch (model STA 409PC/LUXX) TGA while heating in air from 25 to $1000^{\circ} \mathrm{C}$ at $40^{\circ} \mathrm{C} / \mathrm{min}$. Offgas from the sample was analyzed using a Pfeiffer ThermoStar (model GSD 301TS) MS.

\section{$\underline{\text { Offgas Characterization }}$}

Prior to the dissolution of the HEU in HB-Line, the potential to generate an offgas containing $\mathrm{H}_{2}$ was evaluated. The concentration of $\mathrm{H}_{2}$ in the offgas must not exceed $25 \%$ of the lower flammability limit in air (4 vol\%).[1] To perform the measurements, approximately $2.5 \mathrm{~g}$ of material from each INEEL sample were dissolved using laboratory-scale equipment designed for offgas generation measurements and sampling. The equipment consisted of a cylindrical glass vessel with a $30-40 \mathrm{~mL}$ capacity for holding the dissolving solution connected to a gas sampling bulb, vacuum source, and inverted graduated cylinder immersed in water to collect and measure the volume of gas. A sketch of the system is shown on Figure 1.

The dissolutions were initiated by measuring the mass of HEU (by difference) and transferring the sample into the dissolving vessel. The system was sealed and evacuated until water nearly filled the graduated cylinder. A $17 \mathrm{~mL}$ aliquot of nominally $3.5 \mathrm{M} \mathrm{HNO}_{3}$ was added to the dissolving vessel using a syringe and the septum on the top of the vessel. The use of $17 \mathrm{~mL}$ of solution to dissolve $2.5 \mathrm{~g}$ of material results in the same solids to liquid ratio as desired in the HB-Line dissolvers. A starting $\mathrm{HNO}_{3}$ concentration of $3.5 \mathrm{M}$ would result in a final concentration of $2.3 \mathrm{M}$ assuming the material was pure $\mathrm{UO}_{3}$. Once the acid addition was complete, stirring was initiated and the solution heated to $40-60^{\circ} \mathrm{C}$ by heating the water bath on the hot plate/stirrer. A summary of the conditions used to perform the dissolutions is provided in Table 1. 
Table 1 Summary of Conditions for Offgas Characterization Experiments

\begin{tabular}{cccc}
\hline \hline $\begin{array}{c}\text { Experiment } \\
\text { ID }\end{array}$ & $\begin{array}{c}\text { HEU } \\
\text { Mass } \\
(\mathrm{g})\end{array}$ & $\begin{array}{c}\text { Volume } \\
3.5 \mathrm{M} \mathrm{HNO}_{3} \\
(\mathrm{~mL})\end{array}$ & $\begin{array}{c}\text { Temperature } \\
\left({ }^{\circ} \mathrm{C}\right)\end{array}$ \\
\hline $746-1$ & 2.73 & 17.0 & $40-60$ \\
$747-1$ & 2.60 & 17.0 & $40-60$ \\
\hline
\end{tabular}

The temperature was monitored using a thermocouple immersed in the water bath. As the material dissolved, offgases were collected by the displacement of water from the graduated cylinder. The removable gas sample bulb provided the capability to collect and analyze a sample of the offgas upon completion of the dissolution. The dissolutions were terminated by visual observation when the solutions no longer appeared to contain $\mathrm{UO}_{3}$ powder; although, a small amount of fine black solids could still be seen.

Following completion of the dissolutions, the dissolving solutions were cooled and filtered using a coarse glass frit; however, the porosity of the frit was too large to retain the black solids. The solids were removed by centrifuging and decanting the liquid. The solids did not dissolve in hydrochloric acid which indicated they did not contain $U$. The volume of the dissolving solution, which included deionized water used to rinse the dissolver and filter, was determined by measuring the mass and specific gravity of the solution. Samples of the dissolving solutions were prepared for total $U$ and trace metal analyses by transferring a $1 \mathrm{~mL}$ aliquot into plastic sample vials containing $9 \mathrm{~mL}$ of deionized water. Dilution of the dissolving solution was necessary to prevent the transfer of accountable quantities of ${ }^{235} \mathrm{U}$ in the samples. The diluted samples were analyzed for total $U$ by inductively coupled plasma - mass spectroscopy (ICP-MS) and trace metals by inductively coupled plasma - emission spectroscopy (ICP-ES). Samples of the $\mathrm{HNO}_{3}$ solution prepared for the dissolutions and the diluted dissolving solutions were analyzed for free acid by titration.

\section{Timed Dissolution Experiments}

The time required to achieve complete dissolution of the HEU was measured in a series of smallscale experiments in which nominally $2.5 \mathrm{~g}$ of material were dissolved in $17 \mathrm{~mL}$ of nominally $3.5 \mathrm{M} \mathrm{HNO}_{3}$. The dissolutions were performed in a $50 \mathrm{~mL}$ beaker with the pour spout removed. A watch glass filled with water was placed on top of the beaker to reduce the evaporation rate of the dissolving solution. A thermometer was inserted through the watch glass into the dissolving solution using a feedthrough equipped with a compression fitting. A magnetic stir bar was added to the beaker during each dissolution and the beaker was heated and stirred using a hot plate/stirrer. The dissolving temperatures ranged from ambient $\left(23^{\circ} \mathrm{C}\right)$ to $80^{\circ} \mathrm{C}$.

Three experiments were performed in which the magnetic stirrer was periodically (every 0.25 or $0.50 \mathrm{~h}$ ) switched-off and solids allowed to settle for $1 \mathrm{~min}$ prior to removing a $200 \mu \mathrm{L}$ aliquot of the dissolving solution. The $200 \mu \mathrm{L}$ aliquot was transferred to a glass sample vial containing $2000 \mu \mathrm{L}$ of deionized water. A small sample of the dissolving solution was removed to conserve solution and prevent the transfer of accountable amounts of ${ }^{235} \mathrm{U}$ in the analytical samples. Dissolution times for these experiments ranged from 2-4 h. Following the removal of the last 
sample for $\mathrm{U}$ analysis, a sample of the dissolver solution was removed for a free acid analysis. The $200 \mu \mathrm{L}$ aliquot was transferred to a glass sample vial containing $2000 \mu \mathrm{L}$ of deionized water. The samples were analyzed for total U by ICP-MS and free acid by titration.

The calibrations of the 200 and $1000 \mu \mathrm{L}$ pipettes used to prepare the samples were checked by measuring the mass of deionized water transferred to a beaker. The measurements were performed 10 times for each pipette. Upon review of the data, it was clear that the errors associated with the transfers were much less than the error associated with the U analysis; therefore, the nominal value of the pipettes could be considered the exact volume for these experiments.

Once the dissolution was complete, the dissolving solution was cooled to ambient temperature and filtered using paper with a $0.45 \mu \mathrm{m}$ pore size. The volume of the filtrate was measured using a $25 \mathrm{~mL}$ graduated cylinder. A small amount of undissolved solids was collected on the filter paper for analysis. After air drying, the solids were examined by x-ray diffraction to identify the undissolved materials. Following the analysis of the initial samples, it became apparent that the solids required washing with water to remove uranyl nitrate $\left(\mathrm{UO}_{2}\left(\mathrm{NO}_{3}\right)_{2}\right)$ prior to analysis. The small volume of solids retained enough $\mathrm{UO}_{2}\left(\mathrm{NO}_{3}\right)_{2}$ that its presence dominated the x-ray diffraction spectra. To remove the water-soluble $\mathrm{UO}_{2}\left(\mathrm{NO}_{3}\right)_{2}$, five, $15 \mathrm{~mL}$ aliquots of deionized water were poured through the filter assembly.

In two subsequent experiments, nominally $2.5 \mathrm{~g}$ of the HEU were dissolved in $17 \mathrm{~mL}$ of $3.5 \mathrm{M}$ $\mathrm{HNO}_{3}$ at $80^{\circ} \mathrm{C}$. The dissolution time for each experiment was $1.5 \mathrm{~h}$. These experiments were performed to quantify the amounts of $U$ and trace metal impurities in the two samples from the INEEL. The dissolutions were performed in the same manner as the previous three, except the dissolving solution was not periodically sampled. After dissolving for $1.5 \mathrm{~h}$, the solution was allowed to cool to ambient temperature and filtered. The volume of the dissolving solution was then measured using a $25 \mathrm{~mL}$ graduated cylinder. Samples of the solutions were prepared for total $\mathrm{U}$, trace metal, and free acid analyses by transferring a $1 \mathrm{~mL}$ aliquot into plastic sample vials containing $9 \mathrm{~mL}$ of deionized water. Triplicate samples of the solution were analyzed for total U by ICP-MS. Samples of the solution were analyzed for trace metals by ICP-ES and free acid by titration.

A summary of the process conditions used to perform the dissolutions and the sampling frequency are given in Table 2.

Table 2 Summary of Conditions for Timed Dissolution Experiments

\begin{tabular}{cccccc}
\hline \hline $\begin{array}{c}\text { Experiment } \\
\text { ID }\end{array}$ & $\begin{array}{c}\text { HEU } \\
\text { Mass } \\
(\mathrm{g})\end{array}$ & $\begin{array}{c}\text { Volume } \\
3.5 \mathrm{M} \mathrm{HNO}_{3} \\
(\mathrm{~mL})\end{array}$ & $\begin{array}{c}\text { Temperature } \\
\left({ }^{\circ} \mathrm{C}\right)\end{array}$ & $\begin{array}{c}\text { Dissolution } \\
\text { Time } \\
(\mathrm{h})\end{array}$ & $\begin{array}{c}\text { Sampling } \\
\text { Frequency } \\
(\mathrm{h})\end{array}$ \\
\hline $746-2$ & 2.531 & 17.0 & 60 & 2.00 & 0.25 \\
$747-2$ & 2.595 & 17.0 & 60 & 2.00 & 0.25 \\
$747-3$ & 2.573 & 17.0 & 23 & 4.00 & 0.50 \\
$746-3$ & 2.441 & 17.0 & 80 & 1.50 & 1.50 \\
$747-4$ & 2.501 & 17.0 & 80 & 1.50 & 1.50 \\
\hline
\end{tabular}




\section{This page was intentionally left blank.}




\section{Results and Discussion}

\section{$\underline{\text { X-ray Diffraction Analysis }}$}

The x-ray diffraction spectra for the two INEEL HEU samples (746 and 747) are shown on Figures 2 and 3, respectively. The spectra are almost identical showing only $\mathrm{UO}_{3}$ and two hydrated forms of $\mathrm{UO}_{3}$ associated with one molecule of water $\left(\mathrm{UO}_{3} \cdot \mathrm{H}_{2} \mathrm{O}\right)$. The intensity of the peaks assigned to one of the hydrated forms is very strong suggesting that the HEU may contain a significant amount of water. The amount of water and other volatiles in the samples was quantified by thermogravimetric analyses discussed in the following section.

\section{Thermogravimetric Analysis}

Based on the indication provided by the x-ray diffraction analysis that the samples of HEU from the INEEL contained a significant amount of water, a thermogravimetric analysis was performed for each sample. The TGA curves are shown on Figures 4 and 5. The mass loss from sample 746 (Figure 4) and 747 (Figure 5) were 8.1 and 8.6\%, respectively. The offgas from the thermogravimetric analysis of sample 746 was analyzed by the attached MS. The MS was not operational when the analysis of sample 747 was performed. The offgas from sample 746 was predominately water. Trace amounts of nitrogen oxides and carbon dioxide were seen indicating the presence of very minor amounts of nitrate and carbon. Since the shape of the TGA curves for both samples are nearly the same, it would be a reasonable assumption that the composition of the offgas generated during the heating of sample 747 was primarily water.

It should be noted that a portion of the mass loss at temperatures above $600^{\circ} \mathrm{C}$ could be attributed to the conversion of $\mathrm{UO}_{3}$ to $\mathrm{U}_{3} \mathrm{O}_{8}$ (triuranium oxtaoxide) (equation 1); however, heating the $\mathrm{HEU}$ in air during the thermogravimetric analyses prevented the detection of any oxygen $\left(\mathrm{O}_{2}\right)$ liberated from the sample.

$$
3 \mathrm{UO}_{3(\mathrm{~s})} \rightarrow \mathrm{U}_{3} \mathrm{O}_{8(\mathrm{~s})}+\frac{1}{2} \mathrm{O}_{2(\mathrm{~g})}
$$

Many $\mathrm{U}$ compounds (including $\mathrm{UO}_{3}$ ) decompose to $\mathrm{U}_{3} \mathrm{O}_{8}$ above $650^{\circ} \mathrm{C}$.[2] In fact, $\mathrm{U}_{3} \mathrm{O}_{8}$ is conveniently prepared by heating $\mathrm{UO}_{3}$ to nominally $650^{\circ} \mathrm{C}$. The theoretical decrease in mass during the $\mathrm{UO}_{3}$ to $\mathrm{U}_{3} \mathrm{O}_{8}$ conversion is $1.88 \%$. Icenhour [3] measured the mass loss from $\mathrm{UO}_{3}$ during thermogravimetric analysis using material prepared by thermal decomposition of uranyl nitrate hexahydrate. A $1.78 \%$ mass loss beginning at $570^{\circ} \mathrm{C}$ was attributed to the liberation of $\mathrm{O}_{2}$ during the conversion to $\mathrm{U}_{3} \mathrm{O}_{8}$. However, the sample heating rate for these analyses was much slower $\left(1\right.$ or $2^{\circ} \mathrm{C} / \mathrm{min}$ versus $40^{\circ} \mathrm{C} / \mathrm{min}$ ) compared to the heating rated used to analyze the INEEL samples. For this reason, a complete conversion to $\mathrm{U}_{3} \mathrm{O}_{8}$ is doubtful. The MS used to analyze the offgas from sample 746 also detected water in the offgas at $600^{\circ} \mathrm{C}$. This may have been due to the relatively fast heating rate. 


\section{$\underline{\text { Offgas Characterization }}$}

Essentially no offgases accumulated in the inverted graduated cylinder as the HEU in the two INEEL samples dissolved in the test apparatus. This observation is consistent with the results from the $\mathrm{x}$-ray diffraction analysis which showed that the only significant forms of $\mathrm{U}$ were $\mathrm{UO}_{3}$ and $\mathrm{UO}_{3} \cdot \mathrm{H}_{2} \mathrm{O}$. These compounds dissolve in $\mathrm{HNO}_{3}$ by equations (2) and (3).

$$
\begin{gathered}
\mathrm{UO}_{3(\mathrm{~s})}+2 \mathrm{HNO}_{3(\mathrm{l})} \rightarrow \mathrm{UO}_{2}\left(\mathrm{NO}_{3}\right)_{2(\mathrm{aq})}+\mathrm{H}_{2} \mathrm{O}_{(\mathrm{l})} \\
\mathrm{UO}_{3} \cdot \mathrm{H}_{2} \mathrm{O}_{(\mathrm{s})}+2 \mathrm{HNO}_{3(\mathrm{l})} \rightarrow \mathrm{UO}_{2}\left(\mathrm{NO}_{3}\right)_{2(\mathrm{aq})}+2 \mathrm{H}_{2} \mathrm{O}_{(\mathrm{l})}
\end{gathered}
$$

Neither equation (2) or (3) predicts the generation of an offgas which is consistent with the observations during the experiments. The generation of $\mathrm{H}_{2}$ during the dissolution of the HEU is not a concern. Additional data generated during these experiments are discussed and compared with the results from the time dissolution experiment in the following section.

\section{$\underline{\text { Timed Dissolution Experiments }}$}

The $\mathrm{U}$ analyses for the samples generated during the dissolution experiments in which $200 \mu \mathrm{L}$ aliquots were periodically removed from the dissolving solution are presented in Appendix A. Before the concentrations can be correlated with the dissolution time, they must be corrected for the change in volume which occurred as a result of sample removal and evaporation losses. A small correction must also be made for the dissolved $U$ removed in samples prior to completing the experiment. The procedure used to correct the concentrations and the calculated values is presented in Appendix B.

The corrected $\mathrm{U}$ concentrations for the dissolution experiments are plotted as a function of sample time on Figure 6. Examination of the data shows that complete dissolution of the U was obtained in 15-30 min even for the dissolution performed at ambient temperature $\left(23^{\circ} \mathrm{C}\right)$. This result is not surprising, as $\mathrm{UO}_{3}$ is readily soluble in $\mathrm{HNO}_{3}$. [4] The average $\mathrm{U}$ concentration measured at each sample time for each dissolution experiment is also shown on the figure to illustrate the rapid dissolution. There is extensive scatter about the average concentration which was attributed to variations in the small $(200 \mu \mathrm{L})$ sample size of the concentrated $U$ solution.

Experiment 747-3 was performed at ambient temperature $\left(23^{\circ}\right)$ to evaluate the potential for rapid heat generation during the dissolution of the HEU. The temperature of the dissolving solution was closely monitored during the initial stages of the dissolution. The dissolving solution temperature peaked at $28^{\circ} \mathrm{C}$ about $5 \mathrm{~min}$ into the dissolution. The temperature of the solution then cooled back down to $23^{\circ} \mathrm{C}$. Based on these results, the rapid generation of heat during the dissolution of the HEU is not a processing concern.

During the filtration of the dissolving solutions for each experiment, a small amount (estimated to be $<100 \mathrm{mg}$ ) of black solids was collected on the filter paper. The solids were identified by $\mathrm{x}$-ray diffraction analysis. The spectrum, shown on Figure 7, shows that the solids are graphite. The talc identified in the sample was likely due to handling the solids during sample preparation with plastic gloves which are frequently coated with this material. The source of the graphite in 
the HEU is unknown. One could speculate that the HEU contained a small amount of organic solvent which was converted to graphite during the $\mathrm{UO}_{3}$ production process.

The final U concentrations and volumes for the dissolving solutions generated during the offgas characterization and timed dissolution experiments are given in Table 3. The concentrations were corrected for all dilutions.

Table 3 Measured U Concentrations Following HEU Dissolutions

\begin{tabular}{ccc}
\hline \hline $\begin{array}{c}\text { Experiment } \\
\text { ID }\end{array}$ & $\begin{array}{c}\text { Final U } \\
\text { Concentration } \\
(\mathrm{g} / \mathrm{L})\end{array}$ & $\begin{array}{c}\text { Final Solution } \\
\text { Volume } \\
(\mathrm{mL})\end{array}$ \\
\hline $746-1$ & 56.68 & 26.16 \\
$747-1$ & 36.84 & 41.34 \\
$746-2$ & 113 & 11.7 \\
$747-2$ & 121 & 11.8 \\
$747-3$ & 129 & 14.2 \\
\hline $746-3$ & 110.0 & 16.0 \\
& 100.4 & \\
Mean & 96.0 & \\
Std. Dev. & 102.1 & \\
\hline $746-4$ & 7.2 & \\
& 76.6 & \\
& 101.0 & \\
Mean & 81.1 & \\
Std. Dev. & 86.2 & \\
\hline
\end{tabular}

The mass of $U$ recovered during each dissolution experiment was calculated from the product of the concentrations and volumes given in Table 3. The mass of $U$ recovered in Experiments 746-2, 747-2, and 747-3 was corrected for the mass of $U$ removed during periodic sampling. The initial mass of $\mathrm{UO}_{3}$ dissolved in each experiment was calculated from the difference in the mass of the HEU and volatile components (e.g. water) measured during the thermogravimetric analysis of each sample. The $U$ recovery was then calculated based on the assumption that the oxide was pure ${ }^{235} \mathrm{UO}_{3}$. The calculations are summarized in Table 4.

The data in Table 4 generally show that the measured $U$ mass cannot account for the total $U$ added to the dissolving vessel if ones accounts for volatile components and assumes that the INEEL material is pure ${ }^{235} \mathrm{UO}_{3}$. However, trace metal impurities are present in the HEU and will account for a portion of the missing mass. Elemental analyses were performed on the dissolving solutions from Experiments 746-1, 746-2, 746-3, and 747-4. These results are presented in Appendix C. To estimate the mass of impurities in the HEU, the mass of each element was initially calculated from the product of the concentration and the volume of dissolving solution. 
Table 4 U Recovery During HEU Dissolution Experiments

\begin{tabular}{cccccc}
\hline \hline Exp't ID & $\begin{array}{c}\text { Initial HEU } \\
(\mathrm{g})\end{array}$ & $\begin{array}{c}\text { Initial } \mathrm{UO}_{3} \\
(\mathrm{~g})\end{array}$ & $\begin{array}{c}\text { Initial U } \\
(\mathrm{g})\end{array}$ & $\begin{array}{c}\text { Measured U } \\
(\mathrm{g})\end{array}$ & $\begin{array}{c}\text { U Recovery } \\
(\%)\end{array}$ \\
\hline $746-1$ & 2.73 & 2.51 & 2.08 & 1.48 & 71.2 \\
$747-1$ & 2.60 & 2.38 & 1.97 & 1.52 & 77.2 \\
$746-2$ & 2.531 & 2.33 & 1.93 & 1.45 & 75.1 \\
$747-2$ & 2.595 & 2.37 & 1.97 & 1.58 & 80.2 \\
$747-3$ & 2.573 & 2.35 & 1.95 & 2.01 & 103.1 \\
$746-3$ & 2.441 & 2.24 & 1.86 & 1.63 & 87.6 \\
$747-4$ & 2.501 & 2.29 & 1.90 & 1.45 & 76.3 \\
\hline
\end{tabular}

The elemental masses were then converted to an oxide basis assuming the impurities were present as oxides. A small amount of sulfur was detected during the analysis of the dissolving solutions from Experiments 746-3 and 746-4. The sulfur was assumed to be present in the HEU as sulfate and was accounted for as aluminum sulfate $\left(\mathrm{Al}_{2}\left(\mathrm{SO}_{4}\right)_{3}\right)$. A summary of the calculations are presented in Appendix C. The total recovered mass was then calculated as the sum of the $U$ and trace metal impurities (as oxides) and volatile component masses measured during the thermogravimetric analysis. The calculated masses and material balance closure for each experiment are summarized in Table 5. Material balance closures were based on the starting mass of HEU given in Table 4.

Table 5 Material Balances for HEU Dissolution Experiments

\begin{tabular}{ccccc}
\hline \hline Experiment ID & $\mathrm{UO}_{3}$ & Impurities & $\begin{array}{c}\text { Volatile } \\
\text { Components } \\
(\mathrm{mg})\end{array}$ & $\begin{array}{c}\text { Material Balance } \\
\text { Closure } \\
(\%)\end{array}$ \\
\hline $746-1$ & 1780 & 215 & 222 & 81.2 \\
$747-1$ & 1830 & 190 & 223 & 86.3 \\
$746-3$ & 1960 & 237 & 198 & 98.1 \\
$747-4$ & 1750 & 237 & 215 & 88.0 \\
\hline
\end{tabular}

Accounting for impurities and volatile components in the HEU improved the material balance closure considerably; although, significant mass is still unaccounted for in the experiments. The missing mass can likely be attributed to the loss of dissolving solution and mass associated with elements which were not analyzed or detected due to the 1 to 10 sample dilution. Since the volume of the dissolving solutions used for the experiments were relatively small, any loss of solution during filtrations and other solution transfers would have a significant effect on the recovery of $U$ given the concentration in most of the experiments was $60-100 \mathrm{~g} / \mathrm{L}$.

The composition of the HEU dissolved in Experiments 746-1, 747-1, 746-3, and 747-4 can be estimated using the recovered mass of $\mathrm{UO}_{3}$ (Table 5) and oxide impurities (Appendix $\mathrm{C}$ ) and the amount of water (and other volatile components) detected during the TGA-MS analysis. The estimated compositions are presented in Table 6. 
Table 6 Estimated Composition of HEU from the INEEL

\begin{tabular}{|c|c|c|c|c|}
\hline HEU Component & $\begin{array}{l}746-1 \\
(\mathrm{wt} \%)\end{array}$ & $\begin{array}{l}747-1 \\
(w t \%)\end{array}$ & $\begin{array}{l}746-3 \\
(w t \%)\end{array}$ & $\begin{array}{l}747-4 \\
(w t \%)\end{array}$ \\
\hline $\mathrm{UO}_{3}$ & 80.3 & 81.6 & 81.9 & 79.5 \\
\hline Volatiles & 10.0 & 9.9 & 8.3 & 9.8 \\
\hline Impurities & 9.6 & 8.4 & 9.9 & 10.8 \\
\hline $\mathrm{Ag}_{2} \mathrm{O}$ & 0.1 & 0.1 & 0.2 & 0.2 \\
\hline $\mathrm{Al}_{2} \mathrm{O}_{3}$ & 7.0 & 6.6 & 5.0 & 5.7 \\
\hline $\mathrm{BaO}$ & ND & ND & 0.0 & 0.0 \\
\hline $\mathrm{BeO}$ & 0.0 & 0.0 & NM & NM \\
\hline $\mathrm{CaO}$ & 0.2 & ND & 0.1 & 0.1 \\
\hline $\mathrm{Ce}_{2} \mathrm{O}_{3}$ & 0.1 & ND & 0.3 & 0.4 \\
\hline $\mathrm{Cr}_{2} \mathrm{O}_{3}$ & 0.1 & 0.1 & 0.0 & 0.0 \\
\hline $\mathrm{CuO}$ & 0.4 & 0.2 & 0.1 & 0.1 \\
\hline $\mathrm{Fe}_{2} \mathrm{O}_{3}$ & 0.8 & 0.8 & 0.7 & 0.7 \\
\hline $\mathrm{Gd}_{2} \mathrm{O}_{3}$ & ND & ND & 0.2 & 0.2 \\
\hline $\mathrm{La}_{2} \mathrm{O}_{3}$ & ND & ND & 0.1 & 0.1 \\
\hline $\mathrm{Li}_{2} \mathrm{O}$ & ND & ND & 0.0 & 0.0 \\
\hline $\mathrm{MgO}$ & 0.0 & 0.0 & 0.0 & ND \\
\hline $\mathrm{MnO}$ & 0.0 & 0.0 & 0.0 & 0.0 \\
\hline $\mathrm{MoO}_{3}$ & ND & ND & 0.1 & 0.1 \\
\hline $\mathrm{Na}_{2} \mathrm{O}$ & 0.5 & 0.4 & 0.4 & 0.5 \\
\hline $\mathrm{NiO}$ & 0.1 & ND & 0.0 & 0.0 \\
\hline $\mathrm{P}_{2} \mathrm{O}_{5}$ & ND & ND & 0.1 & 0.1 \\
\hline $\mathrm{PbO}$ & ND & ND & 0.1 & 0.1 \\
\hline $\mathrm{Al}_{2}\left(\mathrm{SO}_{4}\right)_{3}$ & ND & ND & 1.6 & 1.6 \\
\hline $\mathrm{Sb}_{2} \mathrm{O}_{3}$ & ND & ND & 0.1 & 0.1 \\
\hline $\mathrm{SiO}_{2}$ & 0.2 & 0.2 & 0.2 & 0.2 \\
\hline $\mathrm{SnO}_{2}$ & ND & ND & 0.1 & 0.1 \\
\hline $\mathrm{SrO}$ & 0.1 & 0.0 & 0.1 & 0.1 \\
\hline $\mathrm{TiO}_{2}$ & 0.0 & ND & 0.1 & 0.1 \\
\hline $\mathrm{V}_{2} \mathrm{O}_{5}$ & ND & ND & 0.0 & 0.0 \\
\hline $\mathrm{ZnO}$ & 0.2 & 0.0 & 0.0 & 0.0 \\
\hline $\mathrm{ZrO}_{2}$ & NM & $\mathrm{NM}$ & 0.3 & 0.3 \\
\hline
\end{tabular}

ND - Not Detected

NM - Not Measured

The estimated composition of the HEU from samples 746 and 747 are quite similar. Both samples contained nominally $80 \mathrm{wt} \% \mathrm{UO}_{3}, 10 \mathrm{wt} \%$ volatiles, and $10 \mathrm{wt} \%$ impurities (as oxides) based on the analyses performed. The volatile components of the material were predominately water based on the TGA-MS results discussed above. The primary impurity in the HEU was $\mathrm{Al}_{2} \mathrm{O}_{3}$ based on the assumption that all impurities were present in the material as oxides. 
The consumption of $\mathrm{HNO}_{3}$ during the $\mathrm{HEU}$ dissolutions was measured by analyzing the initial and final concentrations for each experiment. Data for the experiments are summarized in Table 7.

Table 7 Consumption of $\mathrm{HNO}_{3}$ during HEU Dissolution Experiments

\begin{tabular}{ccccc}
\hline \hline Experiment ID & $\begin{array}{c}\text { Initial } \mathrm{HNO}_{3} \\
\text { Concentration }\end{array}$ & $\begin{array}{c}\text { Measured } \\
\text { Final } \mathrm{HNO}_{3} \\
\text { Concentration } \\
(\mathrm{M})\end{array}$ & $\begin{array}{c}\text { Corrected } \\
\text { Final } \mathrm{HNO}_{3} \\
\text { Concentration } \\
(\mathrm{M})\end{array}$ & $\begin{array}{c}\text { Consumed } \\
\mathrm{HNO}_{3}\end{array}$ \\
\hline $746-1$ & 3.26 & 1.27 & 1.95 & 0.008 \\
$747-1$ & 3.26 & 0.84 & 2.04 & 0.008 \\
$746-2$ & 3.31 & 3.32 & 2.29 & 0.007 \\
$747-2$ & 3.31 & 3.32 & 2.31 & 0.007 \\
$747-3$ & 3.31 & 2.97 & 2.48 & 0.005 \\
$746-3$ & 3.31 & 2.04 & 1.92 & 0.010 \\
$747-4$ & 3.31 & 1.95 & 1.93 & 0.009 \\
\hline
\end{tabular}

The initial $\mathrm{HNO}_{3}$ concentrations were prepared as nominally $3.5 \mathrm{M}$. The measured concentrations were slightly less which was attributed to the starting acid concentration being less than the $15.7 \mathrm{M}$ assumed. The measured final $\mathrm{HNO}_{3}$ concentrations in Table 7 were corrected for the dilutions made prior to sample analysis. The corrected final $\mathrm{HNO}_{3}$ concentrations take into account the change in volume during the dissolutions. In Experiments 746-1 and 747-1, deionized water was used to rinse the dissolver and filter; therefore, the diluted concentrations were referenced back to $17.0 \mathrm{~mL}$. In the other experiments, a portion of the dissolver solution was lost due to evaporation. Assuming no $\mathrm{HNO}_{3}$ was volatilized during the dissolutions, these concentrations were also referenced back to $17.0 \mathrm{~mL}$. The amount of $\mathrm{HNO}_{3}$ consumed during the dissolutions was then calculated from the initial and final $\mathrm{HNO}_{3}$ concentrations and the amount of HEU dissolved (see Table 4). Theoretically, based on equation (2), $1 \mathrm{~g}$ of $\mathrm{UO}_{3}$ would consume 0.007 mole of $\mathrm{HNO}_{3}$ during dissolution. The remainder of the $\mathrm{HNO}_{3}$ consumed in the experiments was utilized to dissolve impurities and a small amount was probably volatilized with water during the (open system) experiments. 


\section{Conclusions}

A series of small-scale experiments was performed to assess the dissolution behavior of samples of HEU from the INEEL. The material was transferred to SRTC as representative samples of excess HEU to be shipped to SRS for disposition. Initially, examination by x-ray diffraction showed that the material was a mixture of $\mathrm{UO}_{3}$ and two monohydrated forms of $\mathrm{UO}_{3}$. Subsequent thermogravimetric analyses showed that the samples contained 8-9 wt\% volatile components which were predominately water. Closed system dissolution experiments performed with several grams of material from each sample showed that essentially no offgas was generated as the material dissolved. This observation was consistent with the presence of $\mathrm{UO}_{3}$ which generates no offgas upon dissolution in $\mathrm{HNO}_{3}$. The generation of $\mathrm{H}_{2}$ during the dissolution of the HEU is not a concern.

Complete dissolution of the $\mathrm{U}$ in the INEEL material was obtained in 15-30 min for experiments performed at $23-60^{\circ} \mathrm{C}$. The dissolutions were carried out in nominally $3.5 \mathrm{M} \mathrm{HNO}_{3}$ using a solids to liquid ratio of $167 \mathrm{~g} / \mathrm{L}$. The experiment performed at $23^{\circ} \mathrm{C}$ demonstrated that rapid heat generation during the dissolution in not a concern. The temperature peaked 5 min into the dissolution at $28^{\circ} \mathrm{C}$ and quickly cooled back down to $23^{\circ} \mathrm{C}$. During filtration of the dissolving solutions, a small amount of black solids was collected on the filter paper. The solids were identified as graphite using x-ray diffraction analysis.

Two additional dissolution experiments were performed at $80^{\circ} \mathrm{C}$ to characterize the $\mathrm{U}$ and impurity content of the HEU. Using the $U$ and elemental analyses of the dissolving solutions and the solutions generated by the offgas characterization experiments, the composition of the HEU was estimated by assuming the impurities generally occurred in the material as oxides. The estimated composition of the two samples was nominally $80 \mathrm{wt} \% \mathrm{UO}_{3}, 10 \mathrm{wt} \%$ volatiles, and $10 \mathrm{wt} \%$ impurities (as oxides). The principal component of the impurities was $\mathrm{Al}_{2} \mathrm{O}_{3}$. Accounting for the $\mathrm{UO}_{3}$, volatile components (e.g. water) and analyzed impurities, material balance closures of $81-98 \%$ were obtained. Analysis of the initial and final $\mathrm{HNO}_{3}$ concentrations of the dissolving solutions showed that $0.005-0.010$ mole of $\mathrm{HNO}_{3}$ was consumed per gram of HEU resulting in a final concentration of nominally $2 \mathrm{M}$ in the series of experiments.

\section{Recommendations}

The proposed HB-Line processing strategy for the HEU is to dissolve up to $3 \mathrm{~kg}$ of material per $18 \mathrm{~L}$ dissolver batch resulting in a final $\mathrm{U}$ concentration in the $100-120 \mathrm{~g} / \mathrm{L}$ range. A wide range of processing conditions can be used to meet this goal. A starting $\mathrm{HNO}_{3}$ concentration of $3.0-3.5 \mathrm{M}$ is recommended based on the desire to achieve a final concentration of nominally $2 \mathrm{M}$. The temperature of the dissolving solution had little effect on the time required to achieve complete dissolution of the HEU; although, a temperature of at least $60-70^{\circ} \mathrm{C}$ is recommended to minimize the amount of undissolved impurities. 


\section{This page was intentionally left blank.}




\section{References}

1. D. R. Lide, Editor, CRC Handbook of Chemistry and Physics, $83^{\text {rd }}$ Edition, CRC Press, Boca Raton, FL, p. 16-16, 2003.

2. J. J. Katz, G. T. Seaborg, and L. R. Morss, Editors, The Chemistry of the Actinide Elements, $2^{\text {nd }}$ Edition, Vol. 1, Chapman and Hall, New York, NY p. 266, 1986.

3. A. S. Icenhour, L. M. Toth, and H. Luo, Water Sorption and Gamma Radiolysis Studies for Uranium Oxides, Report No. ORNL/TM-2001/59, Oak Ridge National Laboratory, Oak Ridge, TN, February 2002.

4. F. A. Cotton and G. Wilkinson, Advanced Inorganic Chemistry, $5^{\text {th }}$ Edition, John Wiley \& Sons, New York, NY, p. 1003, 1988. 


\section{This page was intentionally left blank.}


Figure 1 Offgas Sampling and Measuring Equipment

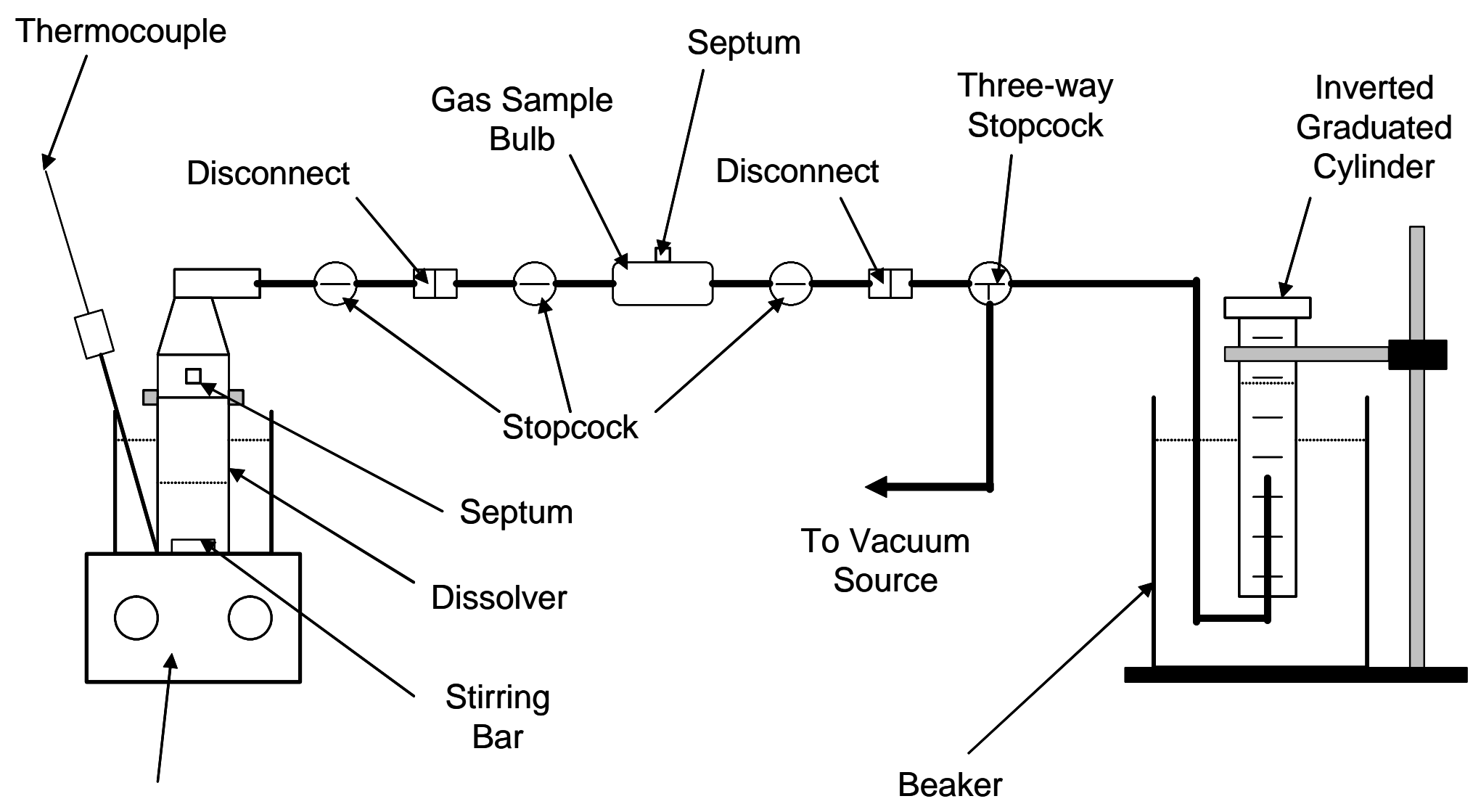

Hot Plate / Stirrer 


\section{This page was intentionally left blank.}


Figure 2 X-ray Diffraction Spectrum from Sample 746

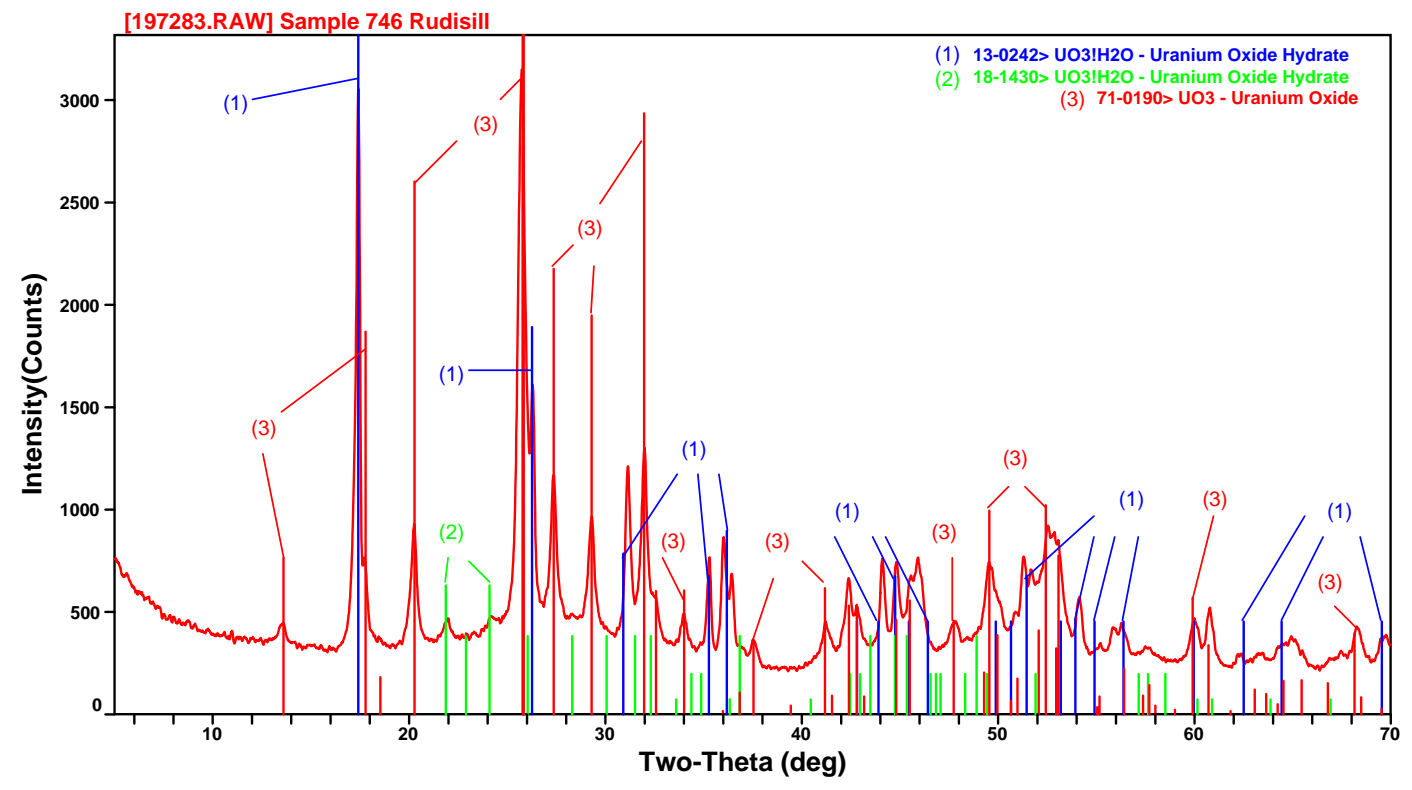

Figure 3 X-ray Diffraction Spectrum from Sample 747

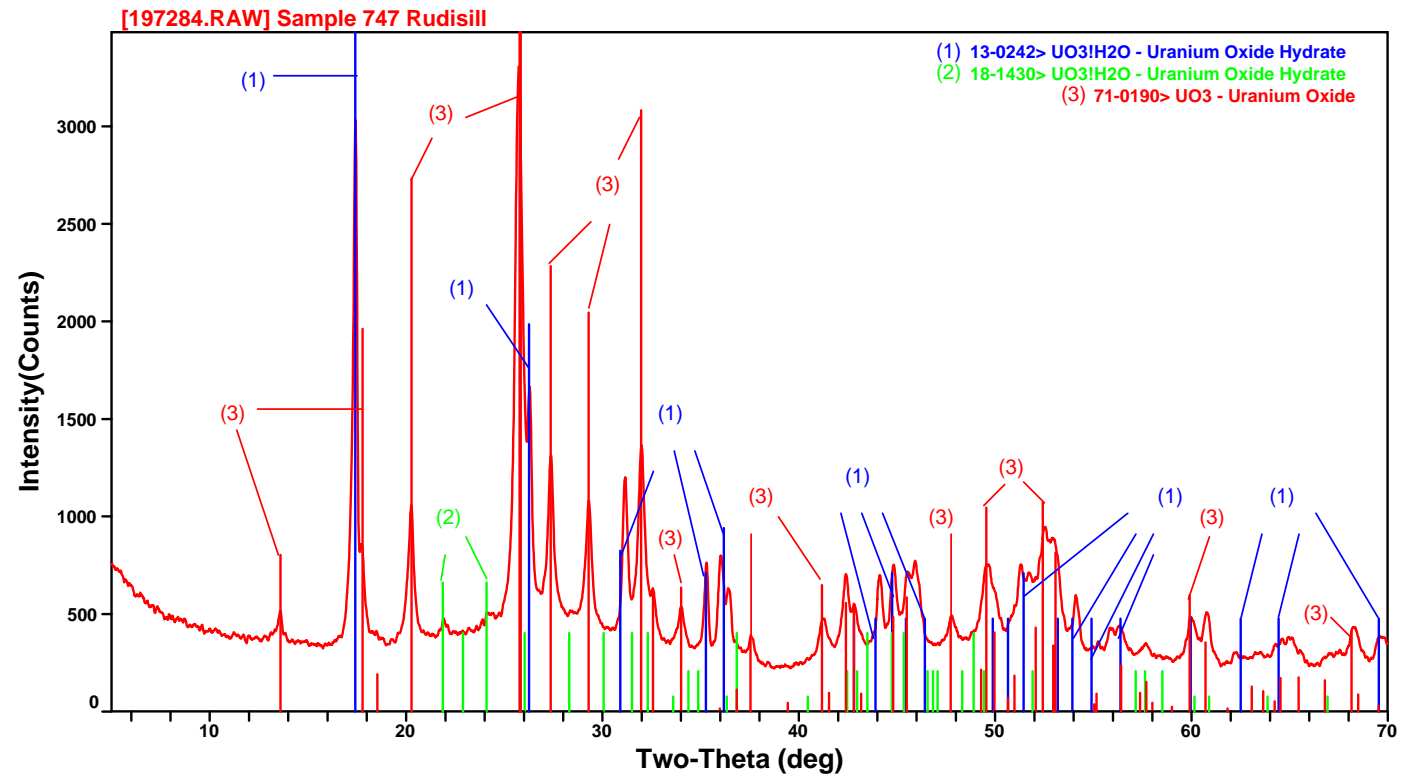




\section{This page was intentionally left blank.}


WSRC-TR-2003-00367

Revision 0

Figure 4 TGA Curve for Sample 746

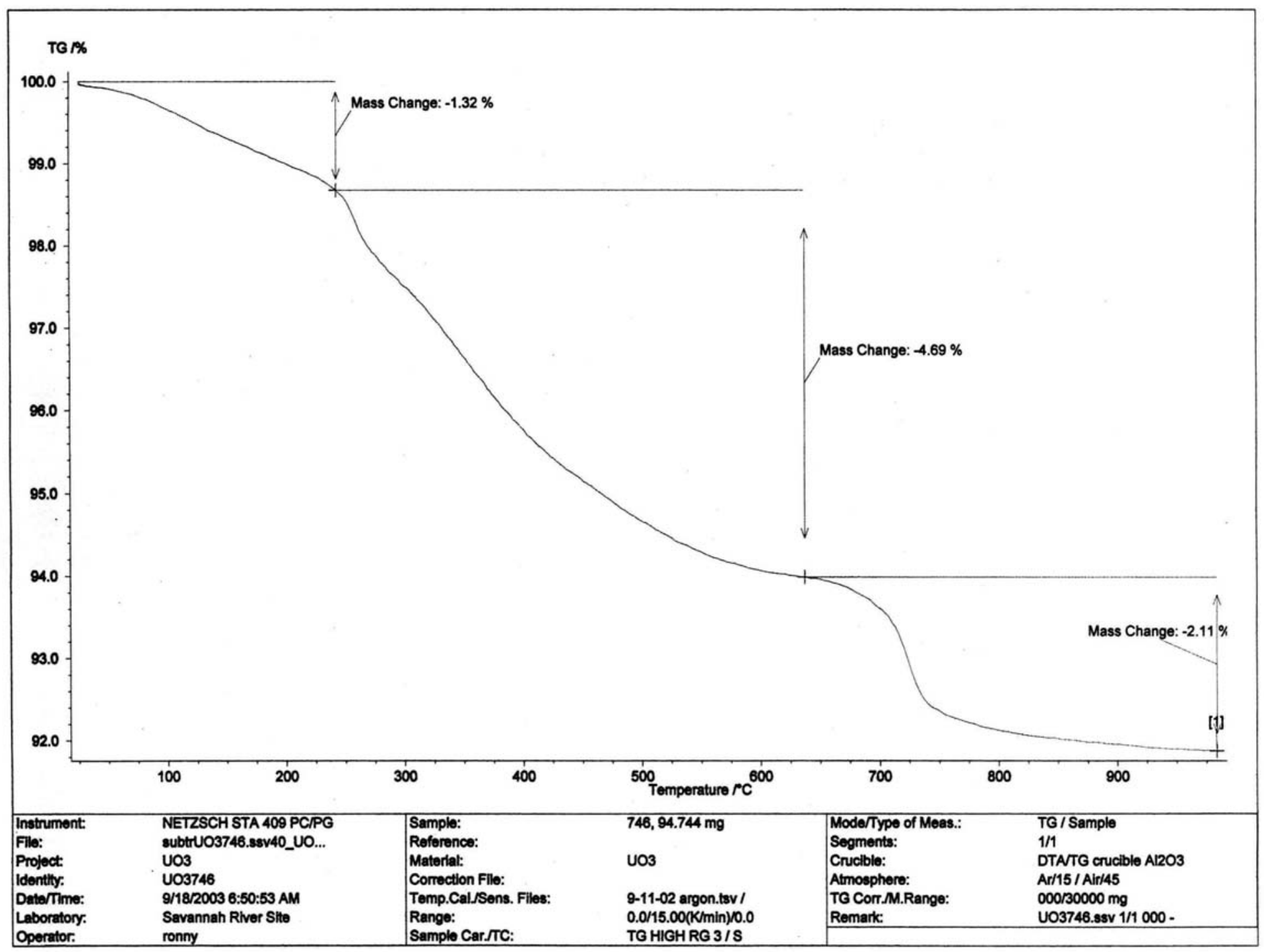




\section{This page was intentionally left blank.}


Figure 5 TGA Curve for Sample 747

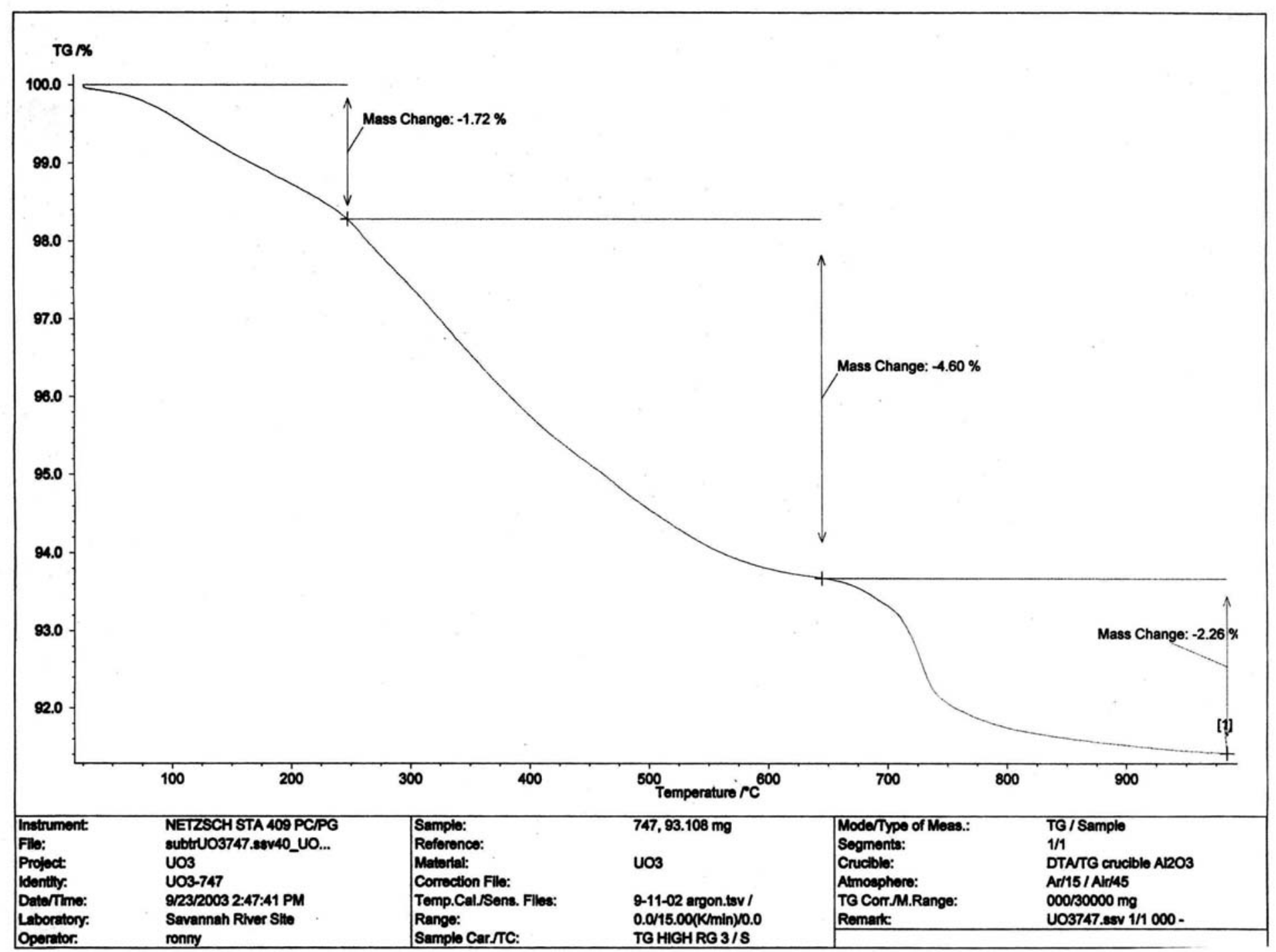




\section{This page was intentionally left blank.}


Figure 6 Dissolution of HEU from the INEEL

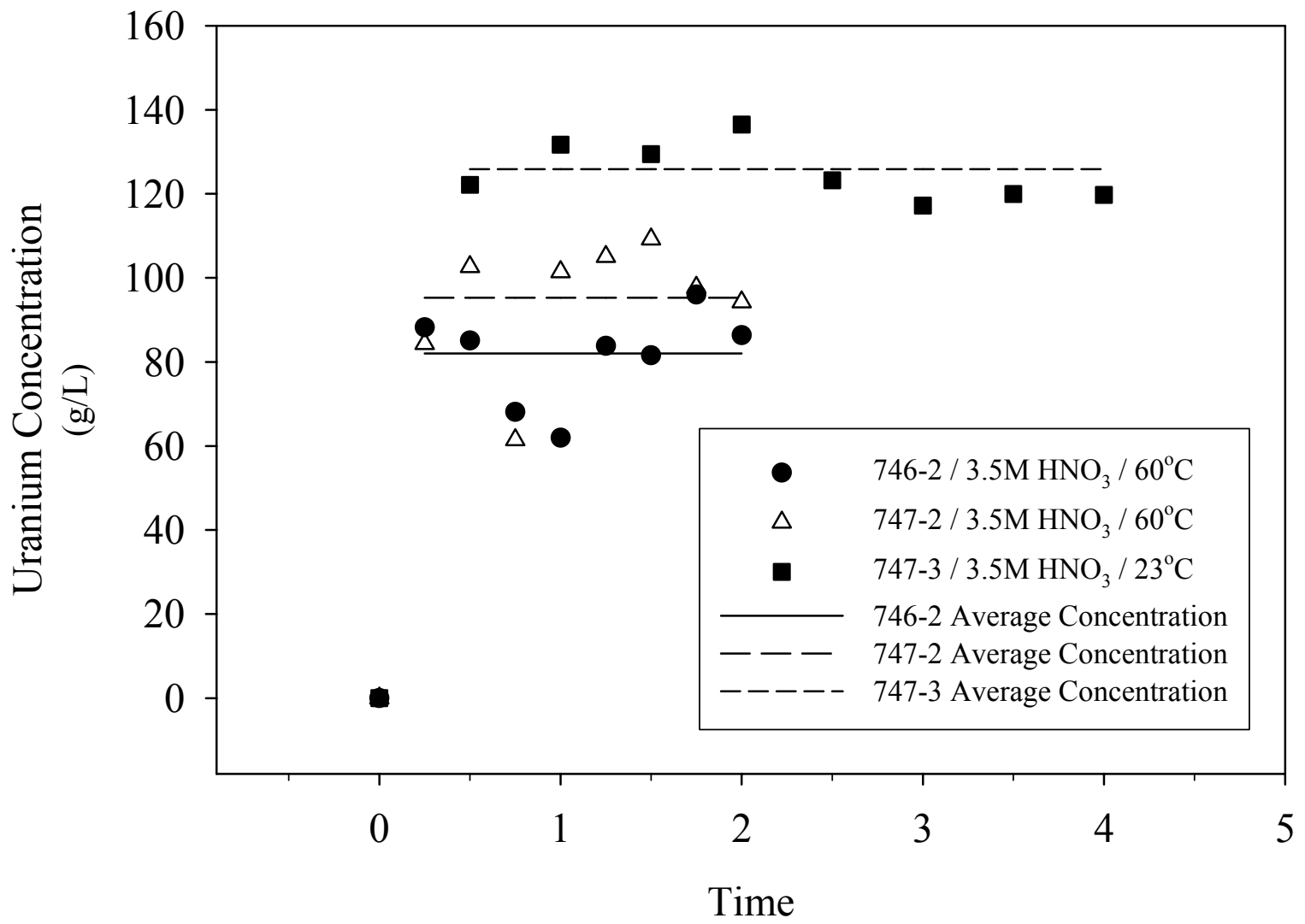

(h) 


\section{This page was intentionally left blank.}


Figure 7 X-ray Diffraction Spectrum of Undissolved Solids

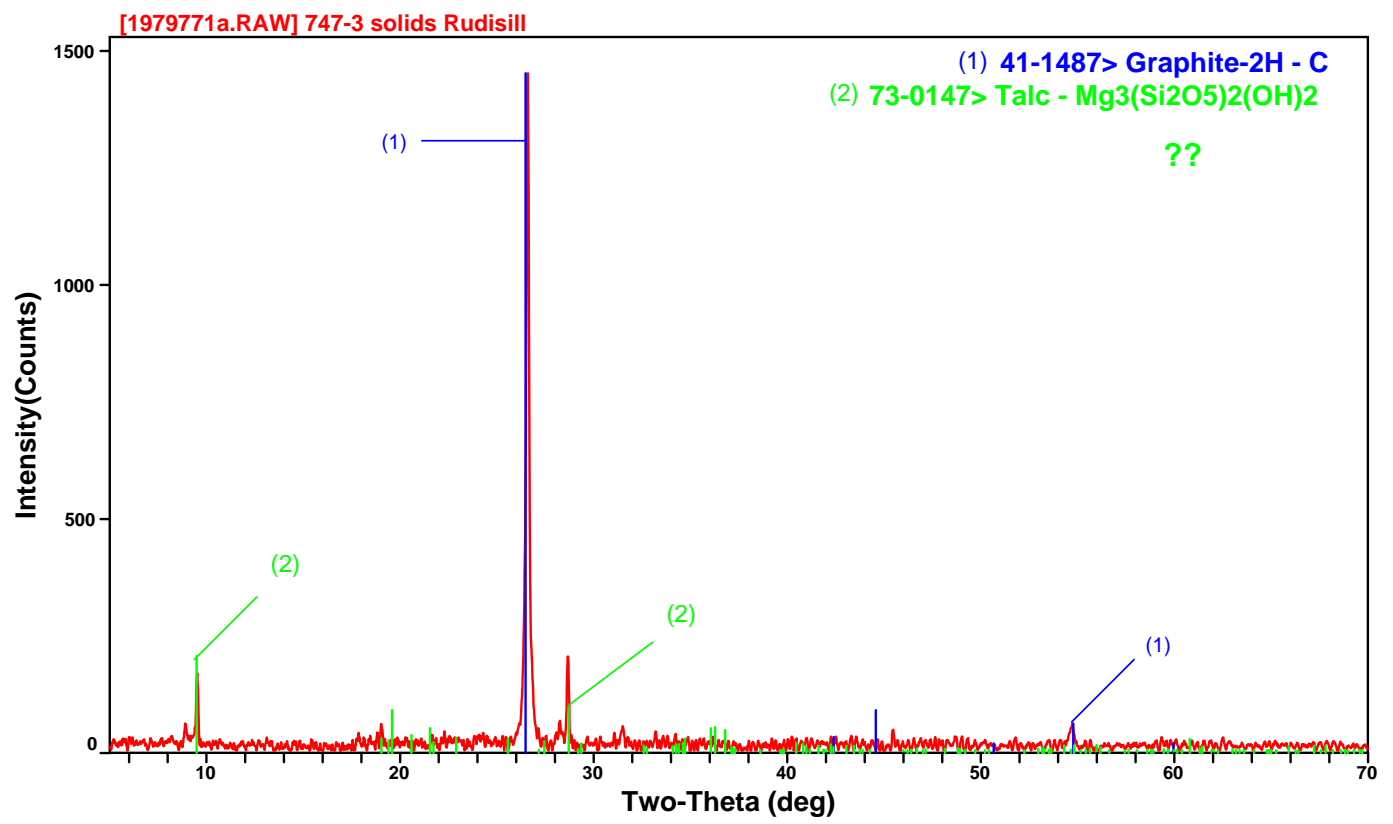




\section{This page was intentionally left blank.}




\section{Appendix A Uranium Analyses from Timed Dissolution Experiments}

The $\mathrm{U}$ analyses for the samples generated during the dissolution experiments in which $200 \mu \mathrm{L}$ aliquots were periodically removed from the dissolving solution are presented in Table A.1. The concentrations were corrected for the $0.2 \mathrm{~mL}$ to $2.2 \mathrm{~mL}$ dilution.

Table A.1 U Analysis for Dissolver Samples

\begin{tabular}{ccccc}
\hline \hline $\begin{array}{c}\text { Dissolution } \\
\text { Time } \\
(\mathrm{hr})\end{array}$ & $\begin{array}{c}\text { Expt. 746-2 } \\
\text { U Conc. } \\
(\mathrm{g} / \mathrm{L})\end{array}$ & $\begin{array}{c}\text { Expt. 747-2 } \\
\text { U Conc. } \\
(\mathrm{g} / \mathrm{L})\end{array}$ & $\begin{array}{c}\text { Dissolution } \\
\text { Time } \\
(\mathrm{hr})\end{array}$ & $\begin{array}{c}\text { Expt. 747-3 } \\
\text { U Conc. } \\
(\mathrm{g} / \mathrm{L})\end{array}$ \\
\hline 0 & 0 & 0 & 0 & 0 \\
0.25 & 90.70 & 86.63 & 0.5 & 123 \\
0.50 & 89.94 & 108.67 & 1.0 & 134 \\
0.75 & 73.70 & 65.93 & 1.5 & 133 \\
1.00 & 68.85 & 114.52 & 2.0 & 142 \\
1.25 & 97.89 & 122.61 & 2.5 & 129 \\
1.50 & 98.47 & 132.12 & 3.0 & 123 \\
1.75 & 121.66 & 121.37 & 3.5 & 128 \\
2.00 & 112.57 & 120.99 & 4.0 & 129 \\
\hline
\end{tabular}




\section{This page was intentionally left blank.}




\section{Appendix B Correction of U Concentrations for Changes in Volume}

The U concentration for each of the samples must be corrected for small changes in volume which occurred due to sample removal and evaporation losses from the beaker. A small correction must also be made for the dissolved $U$ removed in samples prior to completing the experiment. The sample volume was held constant at $200 \mu \mathrm{L}$ during each experiment. The evaporation rate was estimated from the initial and final dissolving solution volumes and the number of samples removed. The calculations are summarized in Table B.1.

Table B.1 Evaporation Rate During U Dissolution Experiments

\begin{tabular}{cccccc}
\hline \hline Expt. No. & $\begin{array}{c}\text { Initial Soln. } \\
\text { Volume } \\
(\mathrm{mL})\end{array}$ & $\begin{array}{c}\text { Final Soln. } \\
\text { Volume } \\
(\mathrm{mL})\end{array}$ & $\begin{array}{c}\text { Total Sample } \\
\text { Volume } \\
(\mathrm{mL})\end{array}$ & $\begin{array}{c}\text { Evaporated } \\
\text { Volume } \\
(\mathrm{mL})\end{array}$ & $\begin{array}{c}\text { Evaporation } \\
\text { Rate } \\
(\mathrm{mL} / \mathrm{hr})\end{array}$ \\
\hline $746-2$ & 17.0 & 11.9 & 1.6 & 3.7 & 1.9 \\
$747-2$ & 17.0 & 12.0 & 1.6 & 3.6 & 1.8 \\
$747-3$ & 17.0 & 14.4 & 1.6 & 1.2 & 0.3 \\
\hline
\end{tabular}

The calculations in Table B.1 assume the evaporation rate was constant during each dissolving experiment and that no other losses of solution occurred. The estimated volumes of solution in the dissolver prior to the removal of each sample are given in Table B.2.

Table B.2 Estimated Dissolver Volume Prior to Sample Removal

\begin{tabular}{ccccc}
\hline \hline $\begin{array}{c}\text { Sample } \\
\text { Time }\end{array}$ & $\begin{array}{c}\text { Expt. 746-2 } \\
\text { Dissolver } \\
\text { Volume } \\
(\mathrm{mL})\end{array}$ & $\begin{array}{c}\text { Expt. 747-2 } \\
\text { Dissolver } \\
\text { Volume } \\
(\mathrm{mL})\end{array}$ & $\begin{array}{c}\text { Sample } \\
\text { Time }\end{array}$ & $\begin{array}{c}\text { Expt. 747-3 } \\
\text { Dissolver } \\
\text { Volume } \\
(\mathrm{mL})\end{array}$ \\
\hline 0 & 17.0 & 17.0 & $(\mathrm{~h})$ & 17.0 \\
0.25 & 16.5 & 16.6 & 0 & 16.9 \\
0.50 & 15.9 & 15.9 & 0.5 & 16.5 \\
0.75 & 15.2 & 15.3 & 1.0 & 16.2 \\
1.00 & 14.6 & 14.6 & 1.5 & 15.8 \\
1.25 & 13.9 & 14.0 & 2.0 & 15.5 \\
1.50 & 13.2 & 13.3 & 2.5 & 15.1 \\
1.75 & 12.6 & 12.7 & 3.0 & 14.8 \\
2.00 & 11.9 & 12.0 & 3.5 & 14.4 \\
\hline
\end{tabular}

The corrected $\mathrm{U}$ concentrations can now be calculated by adjusting for the change in volume and accounting for the small amount of material removed from the dissolving solution in each sample. The generalized expression used to calculate the corrected concentration at sample time $\mathrm{t}\left(\mathrm{C}_{\mathrm{t}^{\text {corrected }}}\right)$ is given as Equation (B.1), 


$$
\mathrm{C}_{\mathrm{t}^{\text {corrected }}}=\frac{\mathrm{C}_{\mathrm{t}} \mathrm{V}_{\mathrm{t}}+\mathrm{V}_{\mathrm{s}} \sum_{\mathrm{i}=1}^{\mathrm{t}-1} \mathrm{C}_{\mathrm{i}}}{\mathrm{V}_{0}}
$$

where $\mathrm{C}_{t}$ and $\mathrm{C}_{\mathrm{i}}$ are the measured concentrations at specific samples times (see Table A.1) and $\mathrm{V}_{\mathrm{t}}, \mathrm{V}_{0}$, and $\mathrm{V}_{\mathrm{s}}$ are the estimated volume at time $\mathrm{t}$ (see Table B.2), the initial volume (17.0 mL), and the sample volume $(0.2 \mathrm{~mL})$, respectively. The corrected concentrations for each experiment are given in Table B.3.

Table B.3 Corrected U Concentrations for Dissolving Experiments

\begin{tabular}{|c|c|c|c|c|}
\hline $\begin{array}{l}\text { Dissolution } \\
\text { Time } \\
\text { (h) } \\
\end{array}$ & $\begin{array}{c}\text { Expt. } 746-2 \\
\text { Corrected } \\
\text { U Conc. } \\
(\mathrm{g} / \mathrm{L})\end{array}$ & $\begin{array}{c}\text { Expt. } 747-2 \\
\text { Corrected } \\
\text { U Conc. } \\
(\mathrm{g} / \mathrm{L})\end{array}$ & $\begin{array}{l}\text { Dissolution } \\
\text { Time } \\
\text { (h) } \\
\end{array}$ & $\begin{array}{c}\text { Expt. } 747-3 \\
\text { Corrected } \\
\text { U Conc. } \\
(\mathrm{g} / \mathrm{L})\end{array}$ \\
\hline 0 & 0 & 0 & 0 & 0 \\
\hline 0.25 & 88.2 & 84.3 & 0.5 & 122 \\
\hline 0.50 & 85.1 & 103 & 1.0 & 132 \\
\hline 0.75 & 68.1 & 61.4 & 1.5 & 129 \\
\hline 1.00 & 61.9 & 101 & 2.0 & 136 \\
\hline 1.25 & 83.8 & 105 & 2.5 & 123 \\
\hline 1.50 & 81.6 & 109 & 3.0 & 117 \\
\hline 1.75 & 96.0 & 97.7 & 3.5 & 120 \\
\hline 2.00 & 86.3 & 94.2 & 4.0 & 120 \\
\hline
\end{tabular}




\section{Appendix C Elemental Analyses for HEU Dissolution Experiments}

The elemental analyses for solutions generated during offgas characterization (746-1 and 747-1) and the timed dissolution experiments (746-3 and 747-4) are presented in Table C.1. The concentrations were corrected for the $1 \mathrm{~mL}$ to $10 \mathrm{~mL}$ dilution. The concentrations measured (by ICP-ES) for $U$ are presented for information only. The values measured by ICP-MS in Table 3 are considered more reliable. Past experience has shown that $U$ concentrations measured by ICP-ES can be biased as much as 10-20\% low compared to other methods of analysis.

Table C.1 Elemental Analysis for HEU Dissolving Solutions

\begin{tabular}{|c|c|c|c|c|}
\hline Element & $\begin{array}{c}\text { 746-1 Conc. } \\
(\mathrm{mg} / \mathrm{L})\end{array}$ & $\begin{array}{c}\text { 747-1Conc. } \\
(\mathrm{mg} / \mathrm{L})\end{array}$ & $\begin{array}{c}\text { 746-3 Conc. } \\
(\mathrm{mg} / \mathrm{L})\end{array}$ & $\begin{array}{c}\text { 747-4Conc. } \\
(\mathrm{mg} / \mathrm{L})\end{array}$ \\
\hline$\overline{\mathrm{Ag}}$ & 7.23 & 4.28 & 28.1 & 27.7 \\
\hline $\mathrm{Al}$ & 312 & 189 & 438 & 429 \\
\hline B & $<5.60$ & $<5.60$ & $<16.2$ & $<16.2$ \\
\hline $\mathrm{Ba}$ & $<3.80$ & $<3.80$ & 2.30 & 2.16 \\
\hline $\mathrm{Be}$ & 0.318 & 0.179 & NM & NM \\
\hline $\mathrm{Ca}$ & 9.58 & $<4.60$ & 6.12 & 6.07 \\
\hline $\mathrm{Cd}$ & $<0.840$ & $<0.840$ & $<0.200$ & $<0.200$ \\
\hline $\mathrm{Ce}$ & 7.56 & $<5.40$ & 43.5 & 42.6 \\
\hline $\mathrm{Cr}$ & 3.35 & 1.98 & 2.96 & 2.46 \\
\hline $\mathrm{Cu}$ & 27.1 & 9.47 & 6.60 & 6.13 \\
\hline $\mathrm{Fe}$ & 45.6 & 28.5 & 68.2 & 65.0 \\
\hline Gd & $<4.68$ & $<4.68$ & 20.9 & 20.7 \\
\hline K & $<188$ & $<188$ & $<95.2$ & $<95.2$ \\
\hline $\mathrm{La}$ & $<1.44$ & $<1.44$ & 7.82 & 7.58 \\
\hline $\mathrm{Li}$ & $<8.60$ & $<8.60$ & 2.77 & 2.61 \\
\hline $\mathrm{Mg}$ & 2.35 & 1.10 & 0.638 & $<0.620$ \\
\hline $\mathrm{Mn}$ & 1.93 & 1.11 & 2.57 & 2.41 \\
\hline Mo & $<10.6$ & $<10.6$ & 9.09 & 8.63 \\
\hline $\mathrm{Na}$ & 29.2 & 17.1 & 46.3 & 45.7 \\
\hline $\mathrm{Ni}$ & 3.86 & $<2.70$ & 5.31 & 4.92 \\
\hline $\mathrm{P}$ & $<13.8$ & $<13.8$ & 7.59 & 6.36 \\
\hline $\mathrm{Pb}$ & $<6.38$ & $<6.38$ & 13.6 & 11.7 \\
\hline $\mathrm{S}$ & $<27.4$ & $<27.4$ & 68.9 & 59.5 \\
\hline $\mathrm{Sb}$ & $<75.6$ & $<75.6$ & 10.9 & 10.9 \\
\hline $\mathrm{Si}$ & 8.02 & 4.51 & 13.4 & 11.4 \\
\hline $\mathrm{Sn}$ & $<9.00$ & $<9.00$ & 11.9 & 11.3 \\
\hline $\mathrm{Sr}$ & 4.01 & 1.88 & 7.20 & 6.96 \\
\hline $\mathrm{Ti}$ & 1.81 & $<1.54$ & 5.2 & 5.03 \\
\hline U & 3930 & 2420 & 6330 & 6160 \\
\hline V & $<1.20$ & $<1.20$ & 2.84 & 2.77 \\
\hline $\mathrm{Zn}$ & 16.4 & 2.10 & 0.867 & 0.948 \\
\hline $\mathrm{Zr}$ & NM & NM & 28.4 & 27.3 \\
\hline
\end{tabular}

NM - Not Measured 
The mass of each element detected during the analysis was calculated from the product of the concentration and the volume of the dissolving solution (see Table 3). The calculated masses are given in Table C.2.

Table C.2 Mass of Elements in HEU Dissolving Solutions

\begin{tabular}{ccccc}
\hline \hline Element & $\begin{array}{c}746-1 \\
\text { Mass } \\
(\mathrm{mg})\end{array}$ & $\begin{array}{c}\text { Mass } \\
(\mathrm{mg})\end{array}$ & $\begin{array}{c}\text { Mass } \\
(\mathrm{mg})\end{array}$ & $\begin{array}{c}\text { Mass } \\
(\mathrm{mg})\end{array}$ \\
$\mathrm{Ag}$ & 2.0 & 1.9 & 4.8 & 5.0 \\
$\mathrm{Al}$ & 154.2 & 147.6 & 120.7 & 124.5 \\
$\mathrm{~B}$ & $\mathrm{ND}$ & $\mathrm{ND}$ & $\mathrm{ND}$ & $\mathrm{ND}$ \\
$\mathrm{Ba}$ & $\mathrm{ND}$ & $\mathrm{ND}$ & 0.4 & 0.4 \\
$\mathrm{Be}$ & 0.2 & 0.2 & $\mathrm{NM}$ & $\mathrm{NM}$ \\
$\mathrm{Ca}$ & 3.5 & $\mathrm{ND}$ & 1.4 & 1.4 \\
$\mathrm{Cd}$ & $\mathrm{ND}$ & $\mathrm{ND}$ & $\mathrm{ND}$ & $\mathrm{ND}$ \\
$\mathrm{Ce}$ & 2.3 & $\mathrm{ND}$ & 8.2 & 8.4 \\
$\mathrm{Cr}$ & 1.3 & 1.2 & 0.7 & 0.6 \\
$\mathrm{Cu}$ & 8.9 & 4.9 & 1.3 & 1.3 \\
$\mathrm{Fe}$ & 17.1 & 16.8 & 15.6 & 15.6 \\
$\mathrm{Gd}$ & $\mathrm{ND}$ & $\mathrm{ND}$ & 3.9 & 4.0 \\
$\mathrm{~K}$ & $\mathrm{ND}$ & $\mathrm{ND}$ & $\mathrm{ND}$ & $\mathrm{ND}$ \\
$\mathrm{La}$ & $\mathrm{ND}$ & $\mathrm{ND}$ & 1.5 & 1.5 \\
$\mathrm{Li}$ & $\mathrm{ND}$ & $\mathrm{ND}$ & 1.0 & 0.9 \\
$\mathrm{Mg}$ & 1.0 & 0.8 & 0.2 & $\mathrm{ND}$ \\
$\mathrm{Mn}$ & 0.7 & 0.6 & 0.5 & 0.5 \\
$\mathrm{Mo}$ & $\mathrm{ND}$ & $\mathrm{ND}$ & 2.2 & 2.2 \\
$\mathrm{Na}$ & 10.3 & 9.5 & 10.0 & 10.3 \\
$\mathrm{Ni}$ & 1.3 & $\mathrm{ND}$ & 1.1 & 1.1 \\
$\mathrm{P}$ & $\mathrm{ND}$ & $\mathrm{ND}$ & 2.8 & 2.4 \\
$\mathrm{~Pb}$ & $\mathrm{ND}$ & $\mathrm{ND}$ & 2.3 & 2.1 \\
$\mathrm{~S}$ & $\mathrm{ND}$ & $\mathrm{ND}$ & 39.2 & 35.6 \\
$\mathrm{Sb}$ & $\mathrm{ND}$ & $\mathrm{ND}$ & 2.1 & 2.2 \\
$\mathrm{Si}$ & 4.5 & 4.0 & 4.6 & 4.1 \\
$\mathrm{Sn}$ & $\mathrm{ND}$ & $\mathrm{ND}$ & 2.4 & 2.4 \\
$\mathrm{Sr}$ & 1.2 & 0.9 & 1.4 & 1.4 \\
$\mathrm{Ti}$ & 0.8 & $\mathrm{ND}$ & 1.4 & 1.4 \\
$\mathrm{~V}$ & $\mathrm{ND}$ & $\mathrm{ND}$ & 0.8 & 0.8 \\
$\mathrm{Zn}$ & 5.3 & 1.1 & 0.2 & 0.2 \\
$\mathrm{Zr}$ & $\mathrm{NM}$ & $\mathrm{NM}$ & 4.5 & 4.6 \\
\hline $\mathrm{ND}-\mathrm{Not} \mathrm{Detected}$ & & & \\
$\mathrm{NM}-\mathrm{Not} \mathrm{Measured}$ & & & \\
& & & &
\end{tabular}

The elemental masses presented in Table C.2 were converted to an oxide basis assuming the impurities were present in the HEU as oxides. A small amount of sulfur was detected during the analysis of the dissolving solutions from Experiments 746-3 and 746-4. The sulfur was assumed 
to be present in the HEU as sulfate and was accounted for as $\mathrm{Al}_{2}\left(\mathrm{SO}_{4}\right)_{3}$. The resulting oxide and sulfate masses are given in Table C.3.

Table C.3 Mass of Oxide Impurities in HEU from the INEEL

\begin{tabular}{|c|c|c|c|c|}
\hline Oxide & $746-1$ & $747-1$ & $746-3$ & $747-4$ \\
\hline & $\begin{array}{l}\text { Mass } \\
(\mathrm{mg})\end{array}$ & $\begin{array}{c}\text { Mass } \\
(\mathrm{mg})\end{array}$ & $\begin{array}{l}\text { Mass } \\
(\mathrm{mg})\end{array}$ & $\begin{array}{l}\text { Mass } \\
(\mathrm{mg})\end{array}$ \\
\hline $\mathrm{Ag}_{2} \mathrm{O}$ & 2.0 & 1.9 & 4.8 & 5.0 \\
\hline $\mathrm{Al}_{2} \mathrm{O}_{3}$ & 154.2 & 147.6 & 120.7 & 124.5 \\
\hline $\mathrm{B}_{2} \mathrm{O}_{3}$ & ND & ND & ND & ND \\
\hline $\mathrm{BaO}$ & ND & ND & 0.4 & 0.4 \\
\hline $\mathrm{BeO}$ & 0.2 & 0.2 & NM & NM \\
\hline $\mathrm{CaO}$ & 3.5 & ND & 1.4 & 1.4 \\
\hline $\mathrm{CdO}$ & ND & ND & ND & ND \\
\hline $\mathrm{Ce}_{2} \mathrm{O}_{3}$ & 2.3 & ND & 8.2 & 8.4 \\
\hline $\mathrm{Cr}_{2} \mathrm{O}_{3}$ & 1.3 & 1.2 & 0.7 & 0.6 \\
\hline $\mathrm{CuO}$ & 8.9 & 4.9 & 1.3 & 1.3 \\
\hline $\mathrm{Fe}_{2} \mathrm{O}_{3}$ & 17.1 & 16.8 & 15.6 & 15.6 \\
\hline $\mathrm{Gd}_{2} \mathrm{O}_{3}$ & ND & ND & 3.9 & 4.0 \\
\hline $\mathrm{K}_{2} \mathrm{O}$ & ND & ND & ND & ND \\
\hline $\mathrm{La}_{2} \mathrm{O}_{3}$ & ND & ND & 1.5 & 1.5 \\
\hline $\mathrm{Li}_{2} \mathrm{O}$ & ND & ND & 1.0 & 0.9 \\
\hline $\mathrm{MgO}$ & 1.0 & 0.8 & 0.2 & ND \\
\hline $\mathrm{MnO}$ & 0.7 & 0.6 & 0.5 & 0.5 \\
\hline $\mathrm{MoO}_{3}$ & ND & ND & 2.2 & 2.2 \\
\hline $\mathrm{Na}_{2} \mathrm{O}$ & 10.3 & 9.5 & 10.0 & 10.3 \\
\hline $\mathrm{NiO}$ & 1.3 & ND & 1.1 & 1.1 \\
\hline $\mathrm{P}_{2} \mathrm{O}_{5}$ & ND & ND & 2.8 & 2.4 \\
\hline $\mathrm{PbO}$ & ND & ND & 2.3 & 2.1 \\
\hline $\mathrm{Al}_{2}\left(\mathrm{SO}_{4}\right)_{3}$ & ND & ND & 39.2 & 35.6 \\
\hline $\mathrm{Sb}_{2} \mathrm{O}_{3}$ & ND & ND & 2.1 & 2.2 \\
\hline $\mathrm{SiO}_{2}$ & 4.5 & 4.0 & 4.6 & 4.1 \\
\hline $\mathrm{SnO}_{2}$ & ND & ND & 2.4 & 2.4 \\
\hline $\mathrm{SrO}$ & 1.2 & 0.9 & 1.4 & 1.4 \\
\hline $\mathrm{TiO}_{2}$ & 0.8 & ND & 1.4 & 1.4 \\
\hline $\mathrm{V}_{2} \mathrm{O}_{5}$ & ND & ND & 0.8 & 0.8 \\
\hline $\mathrm{ZnO}$ & 5.3 & 1.1 & 0.2 & 0.2 \\
\hline $\mathrm{ZrO}_{2}$ & NM & NM & 6.1 & 6.2 \\
\hline Total & 214.6 & 189.5 & 236.8 & 236.5 \\
\hline
\end{tabular}

